\title{
SERODIAGNOSIS OF TORCH INFECTIONS AMONG ABORTED WOMEN IN DUHOK CITY/ KURDISTAN REGION/IRAQ
}

\author{
Manal Adil Murad ${ }^{*}$, Souzan H. Eassa ${ }^{* *}$, and Adel T. M. Al-SAeed ${ }^{* * * *}$ \\ *Dept. of Biology, College of Sciences, University of Duhok, Kurdistan Region-Iraq. \\ ** Dept. of Anatomy, Biology and Histology, College of Medicine, University of Duhok, \\ Kurdistan Region, Iraq. \\ *** Dept. of Medical Microbiology, College of Medicine, University of Duhok, \\ Kurdistan Region- Iraq.
}

(Received: October 7, 2019; Accepted for Publication: December 24, 2019)

\begin{abstract}
TORCH syndrome is a cluster of symptoms caused by congenital infection with (Toxoplasma gondii, Rubella virus, Cytomegalovirus, Herpes simplex virus, and other pathogens such as Hepatitis B virus antigen and syphilis) during the gestation period of pregnancy. The infection might lead to fetal abnormalities or abortion.

Objective: The current study was done to detect TORCH pathogens, hepatitis B virus, and syphilis antigens in women with a previous history of recurrent abortion using serological test in Duhok city. Materials and method: A direct rapid test was used as a serological method for the detection of IgM and IgG antibodies against TORCH pathogens as well as the seropositivity of HBV antigen and syphilis. A total of 90 pregnant women with bad obstetric history were included in the current study throughout April-August 2017 in Duhok City/ Kurdistan Region/Iraq.

Results: The total seropositivity of anti-pathogens (Toxoplasma gondii, Rubella virus, Cytomegalovirus, and Herpes virus) were 19/90(21.1\%), 17/90(18.9), 16/90(17.8), 16/90(17.8\%) and for HBs Ag and syphilis $3 / 90(3.3 \%)$ and syphilis $1 / 90(1.1 \%)$ respectively. The IgM and IgG seropositivity to Toxoplasma gondii, Rubella virus, Cytomegalovirus, and Herpes viruses were (13.3\% and $7.8 \%)$, $(10.0 \%$ and $8.9 \%),(10.0 \%$ and $7.8 \%)$, and $(10.0 \%$ and $7.8 \%)$ respectively. Seroprevalence of antipathogens IgG and IgM antibodies associated with socioeconomic and demographic characteristics were indicated in the results section.

Conclusion: A previous history of pregnancy wastage and the serological test for TORCH infection in addition to HBs Ag and syphilis during current pregnancy must be considered while managing $\mathrm{BOH}$ cases as to reduce the adverse fetal outcomes, the early diagnosis of TORCH using serological methods is highly significant.
\end{abstract}

KEY WORDS: Aborted women, Normal pregnant women, TORCH, Duhok city.

\section{INTRODUCTION}

A bortion is an issue for the socioeconomic status of a society. Several pathogens (such as TORCH complex, $\mathrm{HBs} \mathrm{Ag}$, and syphilis) which affected pregnant women caused severe damage to the fetus, abortions, and congenital abnormalities in women. (Tiwari et al 2016).

Bad obstetric history $(\mathrm{BOH})$ refers to the previous unfavorable fetal outcomes in terms of two or more spontaneous abortions, early neonatal deaths, stillbirths, intrauterine fetal deaths, intrauterine growth retardations, and congenital anomalies. Maternal infections, which are transmitted in utero during various gestational stages, lead to recurrent pregnancy wastage (Kumari et al 2011), the cause of $\mathrm{BOH}$ may relate to genetics, hormones, abnormal maternal immune response, and maternal infection (Turbadkar et al 2003).

The members of TORCH complex agents include Toxoplasma gondii(T. gondii), Rubella virus, Cytomegalovirus (CMV) and Herpes simplex virus (HSV1); and many infectious agents are responsible for the development of maternal infections which can enter the 
intrauterine circulation at any gestational age (Karacan et al 2014).

TORCH pathogens have medical importance for women with bad obstetric history because all of these microorganisms are capable of crossing placental barriers and causing fetal infections and abnormalities (Patel et al 2014). Maternal infections in pregnancy occur during any time of gestation and the severity of the infection depends on many factors such as the virulence of the agents, immune status of the mother, gestational age of the fetus, the route of infection, and the dose of the agent (Mcleod \& Remington 2000).

All the infections have their causative agents and they are generally spread through poor hygienic conditions, contaminated food, water, soil, and airborne respiratory droplets. The infections are more dangerous if the fetus shows microcephaly, intracranial calcifications, rash, intrauterine growth restriction, jaundice, hepatosplenomegaly, elevated transaminase concentrations and thrombocytopenia (Pizzo 2011).

The serological demonstration of the patient sera in vitro, a highly established method chosen in developing countries, is very important to predict the spontaneous abortion (Turbadkar et al 2003).

The current research concerns with serodiagnosis of TORCH infections, $\mathrm{HBs} \mathrm{Ag}$, and Syphilis among 90 aborted women with $\mathrm{BOH}$, as spontaneous abortion and congenital abnormalities. The study was performed in Duhok city, Kurdistan Region.

\section{MATERIALS AND METHODS}

A total of 90 aborted women with $\mathrm{BOH}$ were involved in this study throughout the period from April 1 1 The age range of these women was between 18 to 45 years. Their information was collected by using a special informative questionnaire form including the name, address, age, job, residency, educational level, gestational period, occupation, number of pregnancies, number of recurrent miscarriage, and the physician in charge of the case.

A volume of $5 \mathrm{ml}$ of blood was obtained by vein puncture from the women with abortions; the blood sample was placed in a plain tube without anticoagulant. It was labeled and left standing for 20 minutes at room temperature to clot. Then each tube was centrifuged at $3000 \mathrm{rpm}$ for five minutes to collect the serum (Josheghaniet al 2015). All separated sera were poured into a sterile $2 \mathrm{ml}$ Eppendorf tube; each tube was labeled, named, and then stored at $-20^{\circ} \mathrm{C}$. Later on, the tubes were screened for TORCH IgG and IgM antibodies in addition to Hepatitis B (HBs Ag) and syphilis, by using the direct rapid serological test.

The direct rapid serological test is a chromogenic immunoassay for the qualitative detection of IgG and IgM antibodies. The test and the procedure were done according to the instructions of the manufacturers (Biozek, Netherlands).

This research was approved by the Ethics Committee of Duhok General Health Directorate and the University of Duhok on March 10, 2017, and the reference number was 10052017-4.

\section{Statistical Analysis}

Results were considered to be statistically significant $(P$-values $<0.05)$ using Chi-square test. The statistical analysis of the results was performed by using the statistical program (R) Tutorials for the Chi-square test of independence (Andrew 2013).

\section{RESULTS}

The test was used for TORCH infections, HBs $\mathrm{Ag}$, and syphilis depending on the detection of IgG and IgM antibodies. Table 1 shows that all examined women were distributed as groups according to residency, occupation, education, age of the groups (years), gestational period, and recurrent miscarriage. In regards to residency, $14(15.6 \%)$ cases from rural areas and 76(84.4\%) were from urban areas. Regarding the occupation status, $17(18.9 \%)$ were employed and $73(81.1 \%)$ were housewives. While the educational status, $31(34.3 \%)$ of the cases were literate, and 59 $(65.6 \%)$ were illiterate.

The number of women among different age groups, were 32/90 (35.6\%), 51/90 (56.7\%), $5 / 90(5.6 \%)$, and $2 / 90(2.2 \%)$ among age groups between the ages of 18-24, 25-31, 32-38, and 3945 years respectively. Concerning the gestational period, the number of $1^{\text {st }}$ trimester abortions were $62 / 90(68.9 \%), 2^{\text {nd }}$ trimester $26 / 90(28.9 \%)$ and $3^{\text {rd }}$ trimester $2 / 90(2.2 \%)$. Out of 90 examined pregnant women, $36 / 90(40 \%)$ had single, $38 / 90(42.2 \%)$ double, $13 / 90(14.4 \%)$ triple, and $3 / 90(3.3 \%)$ had four time miscarriages. 
Table (1): Socioeconomic and demographic characteristics among the total examined pregnant women in Duhok city $(\mathrm{n}=90)$.

\begin{tabular}{|c|c|c|c|}
\hline \multirow[t]{2}{*}{ Examined groups characteristics } & \multirow[t]{2}{*}{ Groups } & \multicolumn{2}{|c|}{ Aborted women } \\
\hline & & $\mathrm{n}=90$ & $\%$ \\
\hline \multirow[t]{2}{*}{ Residency } & Rural & 14 & 15.6 \\
\hline & Urban & 76 & 84.4 \\
\hline \multirow[t]{2}{*}{ Occupation } & Employed & 17 & 18.9 \\
\hline & Housewife & 73 & 81.1 \\
\hline \multirow[t]{2}{*}{ Education } & Literate & 31 & 34.4 \\
\hline & Illiterate & 59 & 65.6 \\
\hline \multirow[t]{4}{*}{ Age of the groups (years) } & $18-24$ & 32 & 35.6 \\
\hline & $25-31$ & 51 & 56.7 \\
\hline & $32-38$ & 5 & 5.6 \\
\hline & $39-45$ & 2 & 2.2 \\
\hline \multirow[t]{3}{*}{ Gestational period } & $1^{\text {st }}$ Trimester & 62 & 68.9 \\
\hline & $2^{\text {nd }}$ Trimester & 26 & 28.9 \\
\hline & $3^{\text {rd }}$ Trimester & 2 & 2.2 \\
\hline \multirow[t]{4}{*}{ Recurrent miscarriage } & Once & 36 & 40 \\
\hline & double & 38 & 42.2 \\
\hline & Triple & 13 & 14.4 \\
\hline & Four and more & 3 & 3.3 \\
\hline
\end{tabular}

Table 2 represents the seropositive outcome of aborted women tested $\mathrm{IgG} / \mathrm{IgM}$ antibodies for TORCH 72/90(80\%). The study shows no significant difference in the anti-Toxoplasma gondii, anti-Rubella, anti-HSVl, and anti-CMV
IgG antibodies ( $p>0.05)$. Also, no significant difference in the anti-Rubella, anti-HSVI, and anti- $C M V$ IgM antibodies among 90 aborted women using direct rapid test ( $p>0.05)$.

Table (2): Distribution of TORCH infections, HBV, and syphilis among 90 aborted women using direct rapid test.

\begin{tabular}{|c|c|c|c|c|c|c|c|c|c|c|}
\hline \multirow[t]{2}{*}{ Antigens } & \multicolumn{4}{|c|}{ Positive } & \multicolumn{4}{|c|}{ Negative } & \multicolumn{2}{|c|}{ Total } \\
\hline & IgG & $\%$ & IgM & $\%$ & IgG & $\%$ & $\lg M$ & $\%$ & No. & $\%$ \\
\hline T. gondii & 7 & 7.8 & $12^{*}$ & 13.3 & 83 & 92.2 & 78 & 86.7 & 19 & 21.1 \\
\hline Rubella & 8 & 8.9 & 9 & 10 & 82 & 91 & 81 & 90 & 17 & 18.9 \\
\hline CMV & 7 & 7.8 & 9 & 10 & 83 & 92.2 & 81 & 90 & 16 & 17.8 \\
\hline HSV1\& 2 & 7 & 7.8 & 9 & 10 & 83 & 92.2 & 81 & 90 & 16 & 17.8 \\
\hline HBs Ag & ---- & ---- & ---- & ---- & ---- & --- & ----- & ---- & 3 & 3.3 \\
\hline Syphilis & ---- & ---- & ---- & ---- & ---- & ---- & ----- & ---- & 1 & 1.1 \\
\hline Total & ---- & --- & ---- & --- & --- & --- & ---- & ---- & 72 & 80 \\
\hline
\end{tabular}

Figure 1 illustrates the percentage of results of the total seropositivity of anti-T. gondii 19/90 
(21.1\%), anti-Rubella virus 17/90 (18.9\%), antiCytomegalovirus 16/90(17.8\%), anti-Herpes virus 16/90 (17.8\%), and for $\mathrm{HBs} \mathrm{Ag} 3 / 90$ (3.3\%).

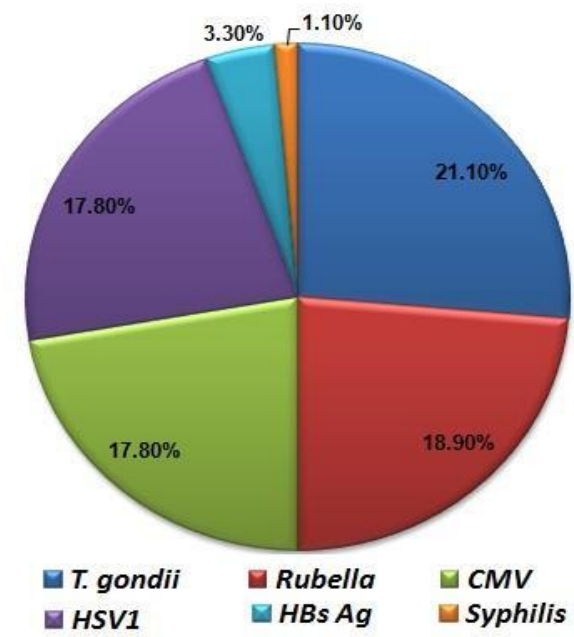

Fig. (1): The Distribution of the total seropositivity of TORCH infections, HBV, and syphilis among 90 aborted women using direct rapid test.

Relating to Seropositivity of Syphilis, among 90 women, only one was detected with Syphilis $1 / 90(1.1 \%)$. She was 28 years old, a housewife, Illiterate, and living in a rural area. She had experienced a double miscarriage, and for the last one she was in the $2^{\text {nd }}$ trimester of pregnancy.

The results that were obtained from the seropositivity of TORCH infection related to the residency status of women with $\mathrm{BOH}$ were represented in Table 3. Regarding the $T$. gondii, $1 / 14(7.1 \%)$ and $6 / 76(7.9 \%)$ of the cases had $\operatorname{IgG}$ antibodies against $T$. gondii in rural and urban areas respectively. While 1/14 (7.1\%) cases and $11 / 76(14.5 \%)$ cases were detected had IgM antibodies against $T$. gondii in rural and urban, respectively. There is a significant difference $(\mathrm{p}<0.05)$, regarding the Rubella virus, between rural and urban residency. Particularly, no anti- rubella $\operatorname{IgG}$ and $\operatorname{IgM}$ were detected in rural areas, while anti-rubella $\operatorname{IgG} 8 / 76(10.5 \%)$ and anti-rubella IgM 9/76 (11.8\%) were detected in urban areas.

Concerning the recognition of anti-CMV IgG, $1 / 14(7.1 \%)$ of rural cases and 6/76 (7.9\%) of urban cases had $\mathrm{IgG}$ antibodies ( $\mathrm{p}>0.05$ ). While $3 / 14(21.4 \%)$ and $6 / 76(7.9 \%)$ of the cases had anti-CMV IgM antibodies related to rural and urban cases $(\mathrm{p}<0.05)$, respectively. On the other hand, no rural women had anti-HSV1 IgG, while $7 / 76(9.2 \%)$ urban women were detected with anti-HSV1 IgG. About 1/14(7.1\%) and $8 / 76(10.5 \%)$ of IgM antibodies belonged to rural and urban women respectively. There were no Anti-HBs Ag antibodies presented in the rural area, but $3 / 76(3.9 \%)$ positive urban cases had been observed.

Table (3): Seropositivity of TORCH infections, HBsAg, and syphilis among women who have had abortions related to residency using direct rapid test.

\begin{tabular}{ccccc}
\hline Pathogens & \multicolumn{4}{c}{ Residency } \\
\cline { 2 - 5 } & \multicolumn{3}{c}{ Rural } & \multicolumn{2}{c}{ Urban } \\
\cline { 2 - 5 } & $\mathbf{n}=\mathbf{1 4}$ & $\mathbf{1 5 . 6 \%}$ & $\mathbf{n}=\mathbf{7 6}$ & $\mathbf{8 4 . 4 \%}$ \\
\hline IgG & 1 & 7.1 & 6 & 7.9 \\
\hline IgM & 1 & 7.1 & 11 & 14.4 \\
\hline Total & 2 & 14.2 & 17 & 22.4 \\
\hline \multicolumn{5}{c}{ Rubella } \\
\hline IgM & 0 & 0 & 8 & 10.5 \\
\hline & 0 & 0 & 9 & 11.8 \\
\hline
\end{tabular}




\begin{tabular}{|c|c|c|c|c|}
\hline Total & 0 & 0 & 17 & 22.3 \\
\hline \multicolumn{5}{|c|}{ CMV } \\
\hline $\lg G$ & 1 & 7.1 & 6 & 7.9 \\
\hline $\lg M$ & 3 & 21.4 & 6 & 7.9 \\
\hline Total & 4 & 28.5 & 12 & 15.8 \\
\hline \multicolumn{5}{|c|}{ HSV1 } \\
\hline $\lg G$ & 0 & 0 & 7 & 9.2 \\
\hline $\lg M$ & 1 & 7.1 & 8 & 10.5 \\
\hline Total & 1 & 7.1 & 15 & 19.7 \\
\hline \multicolumn{5}{|c|}{ HBs Ag } \\
\hline Positive & 0 & 0 & 3 & 3.9 \\
\hline \multicolumn{5}{|c|}{ Syphilis } \\
\hline Positive & 1 & 7.1 & 0 & 0 \\
\hline
\end{tabular}

Table 4 shows the seropositivity of TORCH infections among aborted women relating to their occupational status and educational level. The percentage of anti- $T$. gondii $\operatorname{IgG}$ and $\operatorname{IgM}$ detection was higher in housewives $(23.2 \%)$ than employed women (11.8\%).Regarding the detection of antibodies of anti-T. gondii $\operatorname{IgG}$ (literate $9.7 \%$, Illiterate $6.8 \%$ ) and IgM (literate $12.9 \%$, Illiterate $13.6 \%$ ) there is no significant difference $(p>0.05)$ between literate and illiterate women. Furthermore, the level of anti-rubella virus IgM detected was slightly higher in employed women $2 / 17$ (11.8\%) in comparison to the housewives $7 / 73(9.6 \%)$.
Also, high levels of $\operatorname{IgG}$ antibodies 2/17 $(11.8 \%)$ were detected in employed women and $6 / 73(8.2 \%)$ were detected in housewives. While, the anti-rubella virus IgM detection among literate women was $3 / 31(9.7 \%)$ and illiterate women $6 / 59(10.2 \%)$, there is no significant difference $(\mathrm{p}>0.05)$. However, seropositivity of anti-rubella $\mathrm{IgG}$ belonging to literate women was $4 / 31(12.9 \%)$ and illiterate women was $4 / 59$ $(6.8 \%)$, which presented a significant difference ( $\mathrm{p}<0.05)$. Regarding the detection of Anti-CMV antibodies, there is a highly significant difference $(\mathrm{p}<0.05)$ between the level of IgM 9/73 (12.3\%) in the housewife group and the level of IgM 0/17 $(0 \%)$ in the employed group.

Table (4): Seropositivity of TORCH infections, and HBsAg, among aborted women related to occupation and education level using direct rapid test.

\begin{tabular}{|c|c|c|c|c|c|c|c|c|}
\hline \multirow[t]{3}{*}{ Antibodies } & \multicolumn{4}{|c|}{ Occupation } & \multicolumn{4}{|c|}{ Education } \\
\hline & \multicolumn{2}{|c|}{ housewife } & \multicolumn{2}{|c|}{ Employed } & \multicolumn{2}{|c|}{ Literate } & \multicolumn{2}{|c|}{ Illiterate } \\
\hline & $n=73$ & $81.1 \%$ & $\mathrm{n}=17$ & $18.9 \%$ & $n=31$ & $34.4 \%$ & $n=59$ & $65.6 \%$ \\
\hline \multicolumn{9}{|c|}{ T. gondii } \\
\hline IgG & 6 & 8.2 & 1 & 5.9 & 3 & 9.7 & 4 & 6.8 \\
\hline IgM & 11 & 15.1 & 1 & 5.9 & 4 & 12.9 & 8 & 13.6 \\
\hline Total & 17 & 23.3 & 2 & 11.8 & 7 & 19.9 & 12 & 20.4 \\
\hline \multicolumn{9}{|c|}{ Rubella } \\
\hline $\operatorname{Ig} G$ & 6 & 8.2 & 2 & 11.8 & 4 & 12.9 & 4 & 6.8 \\
\hline IgM & 7 & 9.6 & 2 & 11.8 & 3 & 9.7 & 6 & 10.2 \\
\hline Total & 13 & 17.8 & 4 & 23.6 & 7 & 22.6 & 10 & 17 \\
\hline \multicolumn{9}{|c|}{ CMV } \\
\hline IgG & 4 & 5.5 & 3 & 17.6 & 2 & 6.5 & 5 & 8.5 \\
\hline IgM & 9 & 12.3 & 0 & 0 & 4 & 12.9 & 5 & 8.5 \\
\hline Total & 13 & 17.8 & 3 & 17.6 & 6 & 19.4 & 10 & 17 \\
\hline \multicolumn{9}{|c|}{ HSV1 } \\
\hline $\lg G$ & 5 & 6.8 & 2 & 11.8 & 3 & 9.7 & 4 & 6.8 \\
\hline $\lg M$ & 8 & 11 & 1 & 5.9 & 2 & 6.5 & 7 & 11.9 \\
\hline Total & 13 & 17.8 & 3 & 17.7 & 5 & 16.2 & 11 & 18.7 \\
\hline
\end{tabular}




\begin{tabular}{ccccccccc}
\hline \multicolumn{10}{c}{ HBs Ag } \\
\hline Positive & 1 & 1.4 & 2 & 11.8 & 0 & 0 & 3 & 5.1 \\
\hline
\end{tabular}

Seropositivity of TORCH infections among aborted women relating to their age group, the highest percentage of seropositivity of anti- $T$. gondii antibodies have been observed among the ages of 32-38 years and 25-31 years, which were $40 \%$ and $25.5 \%$ respectively. However, the seropositive rate decreased to $0 \%$ with the increase of age, as shown in Table 5. While the highest seropositive overall antibodies for antiRubella $(21.6 \%)$ were presented among the age group 25-31 years. And, anti-CMV (25.1\%) and anti-HSV1 $(25.1 \%)$ were presented among the age group $18-24$ years $(\mathrm{p}<0.05)$.

Table (5): Seropositivity of TORCH infections, HBs Ag, and syphilis among aborted women related to age using direct rapid test.

\begin{tabular}{|c|c|c|c|c|c|c|c|c|}
\hline \multirow[t]{3}{*}{ Antibodies } & \multicolumn{8}{|c|}{ Age groups (years) } \\
\hline & \multicolumn{2}{|c|}{$18-24$} & \multicolumn{2}{|c|}{$25-31$} & \multicolumn{2}{|c|}{$32-38$} & \multicolumn{2}{|c|}{$39-45$} \\
\hline & $n=32$ & $35.6 \%$ & $\mathrm{n}=51$ & $57.7 \%$ & $n=5$ & $5.6 \%$ & $n=2$ & $2.2 \%$ \\
\hline \multicolumn{9}{|c|}{ T. gondii } \\
\hline $\lg G$ & 3 & 9.4 & 3 & 5.9 & 1 & 20 & 0 & 0 \\
\hline $\operatorname{Ig} M$ & 1 & 3.1 & 10 & 19.6 & 1 & 20 & 0 & 0 \\
\hline Total & 4 & 12.5 & 13 & 25.5 & 2 & 40 & 0 & 0 \\
\hline \multicolumn{9}{|c|}{ Rubella } \\
\hline $\lg G$ & 3 & 9.4 & 5 & 9.8 & 0 & 0 & 0 & 0 \\
\hline $\lg M$ & 3 & 9.4 & 6 & 11.8 & 0 & 0 & 0 & 0 \\
\hline Total & 6 & 18.8 & 11 & 21.6 & 0 & 0 & 0 & 0 \\
\hline \multicolumn{9}{|c|}{ CMV } \\
\hline $\lg G$ & 2 & 6.3 & 4 & 7.8 & 1 & 20 & 0 & 0 \\
\hline $\lg M$ & 6 & 18.8 & 3 & 5.9 & 0 & 0 & 0 & 0 \\
\hline Total & 8 & 25.1 & 7 & 13.7 & 1 & 20 & 0 & 0 \\
\hline \multicolumn{9}{|c|}{ HSV1 } \\
\hline $\lg G$ & 4 & 12.5 & 2 & 3.9 & 0 & 0 & 1 & 50 \\
\hline $\lg M$ & 4 & 12.5 & 5 & 9.8 & 0 & 0 & 0 & 0 \\
\hline Total & 8 & 25.1 & 7 & 13.7 & 0 & 0 & 1 & 50 \\
\hline \multicolumn{9}{|c|}{ HBs Ag } \\
\hline Positive & 1 & 3.1 & 2 & 3.9 & 0 & 0 & 0 & 0 \\
\hline \multicolumn{9}{|c|}{ Syphilis } \\
\hline Positive & 0 & 0 & 1 & 2 & 0 & 0 & 0 & 0 \\
\hline Total & 27 & 84.4 & 41 & 80.4 & 3 & 60 & 1 & 50 \\
\hline
\end{tabular}

Table 6 displays the seropositivity of TORCH infection, $\mathrm{HBs} \mathrm{Ag}$, and syphilis among aborted women in relation to gestational period. In all pathogens, the highest infection rates 62/90(68.9\%) were observed in the first trimester period of pregnancy when compared with other stages. The overall seropositivity rate of $T$. gondii and HSV1, in $3^{\text {rd }}$ trimester, is $1 / 2(50 \%)$ for each. While, the seropositivity rate of anti-CMV IgG is
$1 / 2(50 \%)$, and $1 / 2(50 \%)$ for IgM. Nevertheless, a high percentage of the overall seropositivity in HSV1 has been observed among the $2^{\text {nd }}$ trimester group. These differences were statistically significant $(p<0.05)$. Furthermore, we have found that there are mixed infections in $3^{\text {rd }}$ Trimester. Two aborted women infected with CMV also had other infections. One of the women had toxoplasma while the other had HSV1. 
Table (6): Seropositivity of TORCH infections, $\mathrm{HBs} \mathrm{Ag}$, and syphilis among aborted women related to the gestational period $(\mathrm{n}=90)$.

\begin{tabular}{|c|c|c|c|c|c|c|}
\hline \multirow[t]{2}{*}{ Antibodies } & \multicolumn{2}{|c|}{$1^{\text {st }}$ Trimester } & \multicolumn{2}{|c|}{$2^{\text {nd }}$ Trimester } & \multicolumn{2}{|c|}{$3^{\text {rd }}$ Trimester } \\
\hline & $n=62$ & $\%$ & $\mathrm{n}=26$ & $\%$ & $\mathrm{n}=2$ & $\%$ \\
\hline \multicolumn{7}{|c|}{ T. gondii } \\
\hline $\lg G$ & 3 & 4.8 & 3 & 11.5 & 1 & 50 \\
\hline IgM & 10 & 16.1 & 2 & 7.7 & 0 & 0 \\
\hline Total & 13 & 20.9 & 5 & 19.2 & 1 & 50 \\
\hline \multicolumn{7}{|c|}{ Rubella } \\
\hline $\lg G$ & 8 & 12.9 & 0 & 0 & 0 & 0 \\
\hline IgM & 7 & 11.3 & 2 & 7.7 & 0 & 0 \\
\hline Total & 15 & 24.2 & 2 & 7.7 & 0 & 0 \\
\hline \multicolumn{7}{|c|}{ CMV } \\
\hline $\lg G$ & 5 & 8.1 & 1 & 3.8 & 1 & 50 \\
\hline $\lg M$ & 7 & 11.3 & 1 & 3.8 & 1 & 50 \\
\hline Total & 13 & 19.4 & 2 & 7.6 & 2 & 100 \\
\hline \multicolumn{7}{|c|}{ HSV1 } \\
\hline $\lg G$ & 4 & 6.5 & 3 & 11.5 & 0 & 0 \\
\hline $\operatorname{Ig} M$ & 4 & 6.5 & 4 & 15.4 & 1 & 50 \\
\hline Total & 8 & 13 & 7 & 26.9 & 1 & 50 \\
\hline \multicolumn{7}{|c|}{ HBs Ag } \\
\hline Positive & 2 & 3.2 & 1 & 3.8 & 0 & 0 \\
\hline \multicolumn{7}{|c|}{ Syphilis } \\
\hline Positive & 0 & 0 & 1 & 3.8 & 0 & 0 \\
\hline
\end{tabular}

Concerning the history of the number of recurrent miscarriage, the women who had experienced one or more miscarriage are represented in Figure 2.

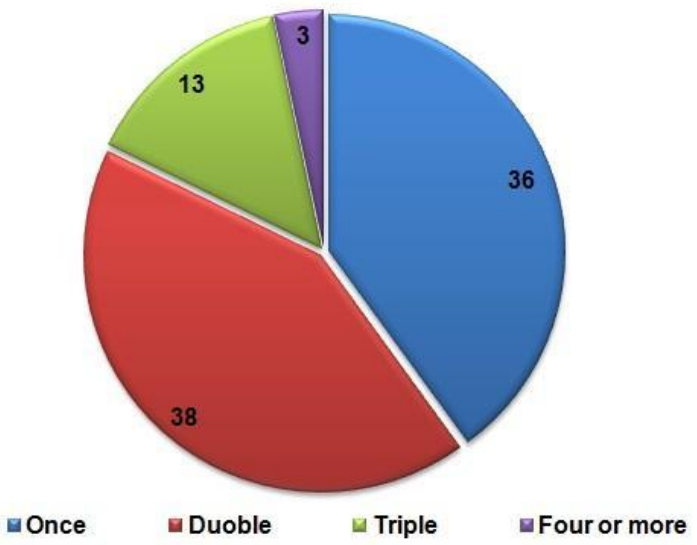

Fig. (2): Distribution of the number of recurrent miscarriage among examined pregnant women with bad obstetric history $(\mathrm{n}=90)$

Out of 90 pregnant women with single miscarriage, $4 / 36(11.1 \%)$ were seropositive for Anti-CMV IgG and 8/36(22.2\%) were seropositive for Anti-CMV IgM, these differences were statistically significant $(\mathrm{p}<0.05)$. Also, 6/36(16.7\%) were seropositive for Anti-Rubella
IgG and 4/36(11.1\%) for Anti-Rubella IgM. The pregnant women with double miscarriage displayed high seropositivity levels of overall anti- $T$. gondii antibodies 9/38(23.8\%), anti- HSVI antibodies $7 / 38(18.5 \%)$, anti-Rubella antibodies 5/38(13.2\%), and 3/38(7.9\%) anti-CMV IgG. In 
addition, pregnant women with triple miscarriage showed the highest overall seropositive levels of anti-HSV1 antibodies 3/13(23.1\%). Moreover, four or more cases of miscarriage were observedin two women. From these cases, $1(33.3 \%)$ was serpositive for IgM of anti- $T$. gondii and, 1(33.3\%) was seropositive for HBs Ag Table 7.

Table (7): Seropositivity of TORCH infections, HBs Ag and syphilis among aborted women $(\mathrm{n}=90)$ who experienced one or more miscarriage by age $18-45$ years

\begin{tabular}{|c|c|c|c|c|c|c|c|c|}
\hline \multirow[t]{3}{*}{ Antibodies } & \multicolumn{8}{|c|}{ No. of miscarriage } \\
\hline & \multicolumn{2}{|c|}{ once } & \multicolumn{2}{|c|}{ Twice } & \multicolumn{2}{|c|}{ Triple } & \multicolumn{2}{|c|}{ Four and more } \\
\hline & $n=36$ & $\%$ & $\mathrm{~N}=38$ & $\%$ & $n=13$ & $\%$ & $\mathrm{n}=3$ & $\%$ \\
\hline \multicolumn{9}{|c|}{ T. gondii } \\
\hline $\lg G$ & 2 & 5.6 & 5 & 13.2 & 0 & 0 & 0 & 0 \\
\hline IgM & 5 & 13.9 & 4 & 10.6 & 2 & 15.4 & 1 & 33.3 \\
\hline Total & 7 & 19.5 & 9 & 23.8 & 2 & 15.4 & 1 & 33.3 \\
\hline \multicolumn{9}{|c|}{ Rubella } \\
\hline $\lg G$ & 6 & 16.7 & 2 & 5.3 & 0 & 0 & 0 & 0 \\
\hline $\lg M$ & 4 & 11.1 & 3 & 7.9 & 2 & 15.4 & 0 & 0 \\
\hline Total & 10 & 27.8 & 5 & 13.2 & 2 & 15.4 & 0 & 0 \\
\hline \multicolumn{9}{|c|}{ CMV } \\
\hline $\lg G$ & 4 & 11.1 & 3 & 7.9 & 0 & 0 & 0 & 0 \\
\hline $\lg M$ & 8 & 22.2 & 0 & 0 & 1 & 7.7 & 0 & 0 \\
\hline Total & 12 & 33.3 & 3 & 7.9 & 1 & 7.7 & 0 & 0 \\
\hline \multicolumn{9}{|c|}{ HSV1 } \\
\hline $\lg G$ & 3 & 8.3 & 2 & 5.3 & 2 & 15.4 & 0 & 0 \\
\hline $\lg M$ & 3 & 8.3 & 5 & 13.2 & 1 & 7.7 & 0 & 0 \\
\hline Total & 6 & 16.61 & 7 & 18.5 & 3 & 23.1 & 0 & 0 \\
\hline \multicolumn{9}{|c|}{ HBs Ag } \\
\hline Positive & 0 & 0 & 2 & 5.3 & 0 & 0 & 1 & 33.3 \\
\hline \multicolumn{9}{|c|}{ Syphilis } \\
\hline Positive & 0 & 0 & 1 & 2.3 & 0 & 0 & 0 & 0 \\
\hline
\end{tabular}

\section{DISCUSSION}

The TORCH complex groups, HBs Ag, and Syphilis in pregnant women lead to adverse outcomes which are initially asymptomatic, and thus are incredibly difficult to diagnose on clinical grounds (Devi et al 2008). A TORCH diagnosis in pregnant women, at the early gestational period (first trimester), is very important in providing early treatment to prevent the congenital infection of fetuses (Press et al 2005).

In the current study, about 90 aborted women, with bad obstetric history, were tested serologically using direct rapid test for the detection of $\operatorname{IgM}$ and $\operatorname{IgG}$ antibodies against TORCH pathogens, HBs Ag, and syphilis. The results of our study showed the seropositivity of
anti-IgG/IgM to $T$. gondii $(7.8 \%) /(12 \%)$, Rubella virus $(8.9 \%) /(9 \%)$, CMV $(7.8 \%) /(9 \%)$, and HSV1 $(7.8 \%) /(9 \%)$, which disagree with the results of a study conducted in the Kashan region of Iran, the seropositivity of $\operatorname{IgM} / \operatorname{IgG}$ to $T$. gondii $(37.5 \%) /(3.8 \%)$, Rubella virus $(92.5 \%) /(0 \%)$, CMV $(98.8 \%) /(5 \%)$, and HSV1 $(91.3 \%) /(7.5 \%)$ (Josheghani et al 2015).

While a study done in Kirkuk agrees with our current results. A total of 252 women with $\mathrm{BOH}$ were tested for the detection of $\operatorname{IgM}$ and $\operatorname{IgG}$ antibodies against TORCH. It showed that the seropositivity of total IgG antibodies for $T$. gondii was34.92\%, Rubella virus 26.68\%, CMV 21.03 $\%$, and HSV1 $16.06 \%$ (Mohammad and Salman, 2014). Also, our study agreed with research conducted in Beijing on a large population of pregnant women with BOH.About 4692 women 
were tested serologically for the detection of IgM and $\mathrm{IgG}$ antibodies by using the ELISA method, the results of anti-TORCH $\operatorname{IgM}$ antibodiesfor Toxoplasma, Rubella virus, CMV, and HSV1 were $183(3.9 \%), 103(2.2 \%), 85(1.8 \%), 497$ (10.6\%) respectively.While IgG antibodies against Toxoplasma, Rubella virus, CMV and HSV1 were $89(1.9 \%), 3270(69.7 \%), 4340$ $(92.5 \%)$ and $4195(89.4 \%)$ respectively (Liet al 2009).

These differences in the prevalence of TORCH infections among aborted women may be related to the unhygienic environment, weak immunity and low level of education.

Regarding residency, unexpected results were found in the present study. A high rate of ( $T$. gondii, Rubella, HSVl, and HbsAg) infection was found among urban women in comparison with rural women, and this may be due to the high number of urban women examined in this study, or to the eating habits as more urban women attend restaurants and consume fast food. These results were in agreement with the results of (AlNahari and Al-Tamimi, 2010) in Yemen.

Regarding the occupation and education status, in the present study a higher number of housewives and illiterate women (17 and 12) had toxoplasmosis compared to employed and literate women (2 and 7), this indicates that housewives have more exposure to sources of infection and were at high risk during their home work such as dealing with raw meat and vegetables, in addition to their outdoor activities such as gardening and cleaning outside the home. Also, the illiterate women were at higher risk high risk for getting an infection, this may be due to the low level of hygiene, and with health education Table 4 . The same result was shown in the study had been conducted by (al-Saeed et al 2015).

The present study also found that the highest percentage of TORCH infection has been observed among the ages from 18-24 years 27/32 (84.4\%), followed by 25-31 years with a percentage of (80.4\%) when compared with other age groups(32-38 years and 39-45 years). These result agreeswith findings of (Al-Taie, 2010) in Iraq, which found that most cases (57\%) with high delivery risk factors recorded belonged to 21-30 years. The age of $18-31$ years was considered the optimum period for childbearing.

In all TORCH agents, the highest infection rate 51/90(56.6\%) was recorded in the first trimester of pregnancy and the lowest rate of infection $2 / 90(2.2 \%)$ was recorded in the third trimester.

In this study, all examined women with $\mathrm{BOH}$ were suffering from abortions either once, twice or more. The percentage of one time was high (36\%) and this is in agreement with the results of many other studies such as (Rajendra et al., 2006) in India which found that maximum number of cases of abortions $(27.27 \%)$ were with single abortion, a possible reasons might be the development of immunity against the infection or other pathogenic causes in case of habitual or repeated abortions.

In conclusion, our study demonstrated that the routine screening for TORCH agents as early detection in pregnant women is required to avoid the risk factor that lead to $\mathrm{BOH}$ development. In addition, the improvement of health education programs in primary health care centers and discussing prophylactic measures are also incredibly crucial in the prevention of such cases.

\section{References}

Al-Nahari, A., and Al-Tamimi A. (2010). Seroprevalence of Anti Toxoplasma gondii IgG and IgM among Pregnant Women in Sana'a Capital and Capital Trusteeship. Scientific Journal of King Faisal University (Basic and applied Sciences), 11, 1431-1439.

Al-Saeed, A.T., Abdulmalek, I.Y., Golik Ismail, H.G. (2015). TOURCH Infections in Mothers With Bod as A Cause of Neonatal Miscarriages and Fetal Malformation in Duhok Province, Kurdistan Region/ Iraq. Journal University of Zakho, 3, 176-186. ISSN: 2410-7549

$\mathrm{Al}$ - Taie, A. (2010). Serological Study for TORCH Infections in Women with High Delivery Risk Factors In Mosul. Tikrit Journal of Pure Science, 15, 193-198.

Gelman A. (2013). G.P-value and statistical practice. Epidemiology 2013; 24:69-72. doi:10.1097/EDE.0b013e31827886f7

Devi, K.S., Devi, Y.G., Singh, N.S., Singh, A.M., Singh, I.D. (2008). Seroprevalence of TORCH in women with still birth in RIMS hospital. Journal of Medical Society, 22, 2-4

Josheghani, S.B., Moniri, R., Taheri, F.B., Sadat, S., Heidarzadeh Z. (2015). The prevalence of serum antibodies in TORCH infections during the first trimester of pregnancy in Kashan, Iran. Iranian Journal of Neonatology, 6, 8-12. doi: 10.22038/IJN.2015.4149

Karacan, M., Batukan, M., Cebi, Z., Berberoglugil, M., Levent, S., Kır, M., Kır, M., Baksu, 
A., Ozel, E., Camlıbel, T. (2014). Screening cytomegalovirus, rubella and Toxoplasma infections in pregnant women with unknown pre-pregnancy serological status. Archives of Gynecology Obstetric Journal, 290, 11151120. doi: 10.1007/s00404-014-3340-3

Kumari, N., Morris, N., Dutta, R. (2011). Is screening of TORCH worthwhile in women with bad obstetric history an observation from eastern Nepal?. Journal of Health, Population, and Nutrition, 29, 77-80. doi: 10.3329/jhpn.v29i1.7569

Li, Z., Yan, C., Liu, P., Yan, R., Feng, Z. (2009). Prevalence of serum antibodies to TORCH among women before pregnancy or in the early period of pregnancy in Beijing. Clin Chim Acta, 403, 212-215. doi: 10.1016/j.cca.2009.03.027.

McLeod, R., Remington, J.S. (2000). Toxoplasmosis (Toxoplasma gondii). In: Behrman RE, Kliegman RM, Jenson HB (ed.), pp1054-1062. Nelson Textbook of pediatrics.16th ed. In Philadelphia, PA: WB Saunders

Mohammad, E.A.K., and Salman, Y. J. (2014). Study of TORCH infections in women with Bad Obstetric History (BOH) in Kirkuk city. Int. J. Curr. Microbiol. App. Sci, 3, 700-709.

Patel, K.K., Shrivastava, G., Bhatambare, G., Bajpai, T. (2014). Antenatal detection of Ig M and Ig G antibodies to Toxoplasma gondii in a hospital from central India. International Journal of Health Systems and Disaster in Mangement , 2, 133-135. doi: 10.4103/2347-9019.142188

Pizzo, J.D. (2011). Focus on diagnosis: congenital Infection (TORCH). Pediatr Review, 32, 537542. doi: 10.1542/pir.32-12-537

Press, C., Montoya, J.G., Remington, J.S. (2005). Use of a single serum sample for the diagnosis of toxoplasmosis in pregnant women and other adults. Journal of Clinical Microbiology, 43, 3481-3483. doi: 10.1128/JCM.43.7.34813483.2005

Rajendra, B. S., Usha, P., Kamlakar, R.K., Khadse, M.S., Qazi Suresh, V. j. (2006). Serological study for TORCH infections in women with bad obstetric history in Nagpur. India. Journal Obstet Gynecol India, 56, 41-43.

Tiwari, S., Arora, B.S., Diwan, R. (2016). TORCH IgM seroprevalence in women with abortions as adverse reproductive outcome in current pregnancy. International Journal of Research in Medical Sciences, 4, 784-788. DOI: http://dx.doi.org/10.18203/23206012.ijrms20160518

Turbadkar, D., Mathur, M., Rele, M. (2003). Seroprevalence of TORCH infection in bad obstetric history. Indian Journal of Medical Microbiology, 21, 108-110. PMID: 17642992 